\title{
On the force of aqueous vapour, in reply to $\mathrm{Mr}$. Moyle
}

\author{
James Apjohn M.D. M.R.I.A.
}

To cite this article: James Apjohn M.D. M.R.I.A. (1843) On the force of aqueous vapour, in reply to Mr. Moyle, Philosophical Magazine Series 3, 22:143, 157-158, DOI: 10.1080/14786444308636337

To link to this article: http://dx.doi.org/10.1080/14786444308636337

册 Published online: 01 Jun 2009.

Submit your article to this journal

Џ Article views: 2

Q View related articles $₫$ 
created beings - and as their ultimate end, the cure of disease, the alleviation of agony, and the prolongation of human life. Gentlemen of yourown valuable profession have given their testimony to the importance of your discoveries, and the Council feels pleasure in rewarding your zeal and talents*. To you, and all who, like you, are employed in these noble pursuits, all here will say with me, may God prosper your labours to His glory and to the happiness of His creatures.

Mr. Da Niell.

The continued intercourse that I have had with you in the Council of the Royal Society increases the pleasure which I experience in giving into your hands this Medat. Electrical Chemistry, at all times of great importance as giving us an insight into the most recondite laws of nature, has now acquired additional interest by the practical purposes to which a Wheatstone, a Spencer, a Jacobi, and others have applied it. Its connection with magnetism seems to promise still greater discoveries than those that have already immortalised a Davy and a Faraday. You have pursued this difficult branch of Chemistry with signal success, and the Council have approved of the recommendation of the Chemical Committee, that one of the Royal Medals should be conferred on you for the valuable papers which you have contributed to our Transactions. I trust that our future volumes may be still more enriched by the result of your scientific labourst.

The following Gentlemen were duly elected Officers and Council for the ensuing year, viz:-

President.-The Marquis of Northampton. Treasurer.-Sir John William Lubbock, Bart., M.A. Secretaries.-Peter Mark Roget, M.D., Samuel Hunter Christie, Esq., M.A. Foreign Secretary.-John Frederic Daniell, Esq. Other Members of the Council.George Biddell Airy, Esq., M.A., A.R.; Francis Baily, Esq.; Martin Barry, M.D.; Henry James Brooke, Esq.; Robert Brown, Esq., D.C.L.; Rev. James Cumming, M.A.; John Thomas Graves, Esq., M.A.; Sir William J. Hooker, K.H., LL.D.; Robert Lee, M.D. ; Gideon A. Mantell, Esq., LL.D.; William Hallows Miller, Esq., M.A.; William H. Pepys, Esq.; George Rennie, Esq.; The Earl of Rosse; William Henry Fox Talbot, Esq. ; Charles Wheatstone, Esq.

XXII. Intelligence and Miscellaneous Articles.

ON THE FORCE OF AQUEOUS VAPOUR, IN REPLY TO MR. MOYLE. BY J. APJOHN, M.D., M.R.I.A.

To the Conductors of the Philosophical Magazine and Journal. Gentrimen,

IN reply to Mr. Moyle's inquiry contained in page 73 of the Philosophical Magazine for last month, I beg to say that my method of reducing to $32^{\circ}$ the pressures mentioned in a short communication of mine to the Royal Irish Academy, "On the force of aqueous vapour within the range of atmospheric temperatures," which you

* See Phil. Mag. vol. xx. p. 509.

+ Ibid. vol. xxi. p. 54. 
have transferred to the November Number of your Journal, consisted in first bringing the observed pressures to what they would be at the neutral point of temperature, applying next the correction for capacity, then bringing the resulting barometric heights to what they would be at $32^{\circ}$, and lastly adding the corrections for capillarity. There is, I need not say, nothing peculiar in this process. Not having by me the portable barometer (one by Newman) which I used in my experiments, I cannot exactly state the neutral points of pressure and temperature, and the corrections for capacity and capillarity peculiar to it, and which are, as usual, engraved upon its mounting. I may mention, however, that the coefficient of mercurial expansion for one degree Fahrenheit which I have employed in the reductions is 0001 ; the number very nearly which results from the well-known experiments of Dulong and Petit. I apprehend that Mr. Moyle has been led into error by supposing me to have used a syphon barometer with moveable scales, an instrument whose indications require to be corrected for temperature alone.

I am, Gentlemen, your obedient Servant,

28 S. Baggott-Street, Jan. 16, 1843.

James Apjohn.

ON THE EXTRAORDINARY DEPRESSION OF THE BAROMETER ON JANUARY 13TH, 1843. BY H. H. WATSON, ESQ.

To the Editors of the Philosophical Magazine and Journal. Gentlemen,

The very extraordinary depression of the barometer which occurred yesterday, will doubtless have been noted by many of your readers; and probably the subjoined account of the observations made by me, at this town, on the height of the mercurial column, will not be unacceptable for publication in your Journal; as, by comparison with the notes made by distant observers, they may assist in showing how far the depression has been general.

\begin{tabular}{|c|c|c|c|c|c|c|}
\hline \multirow{2}{*}{ 13th Jan. 184} & \multicolumn{3}{|c|}{ Height of the } & \multicolumn{3}{|c|}{ Height of the } \\
\hline & 9 А.M. & $27 \cdot 81$ & nch. & Half-past & 3 р.м. & $27 \cdot 81 \mathrm{i}$ \\
\hline & 10 A.M. & $27 \cdot 77$ & $\ldots$ & & 4 р.м. & $27 \cdot 85$ \\
\hline st 1 & 10 A.M. & $27 \cdot 75$ & $\ldots$ & Half-past & 4 P.м. & $27 \cdot 87$ \\
\hline & 11 A.M. & $27 \cdot 73$ & $\ldots$ & & 5 P.M. & $27 \cdot 87$ \\
\hline ast 1 & $11 \mathrm{A.M}$. & $27 \cdot 72$ & $\cdots$ & Half-past & 5 p.M. & $27 \cdot 87$ \\
\hline & 12 & $27 \cdot 72$ & $\cdots$ & & 6 P.M. & 27 \\
\hline past 1 & 12 P.м. & $27 \cdot 72$ & ... & & 7 P.м. & $27 \cdot 94$ \\
\hline & l F:M. & $27 \cdot 73$ & $\cdots$ & & 8 P.M. & $27 \cdot 97$ \\
\hline Ialf-past & 1 P.M. & $27 \cdot 74$ & $\ldots$ & & 9 р.м. & $28 \cdot 01$ \\
\hline & 2 P.M. & $27 \cdot 76$ & $\cdots$ & & 10 P.M. & 03 \\
\hline Ialf- & 2 P.M. & $27 \cdot 77$ & $\cdots$ & & 11 P.M. & $28 \cdot 04$ \\
\hline & 3 P.M. & $27 \cdot 79$ & & & & \\
\hline
\end{tabular}

The greatest depression was from half-past 11 A.M. to half-past 12 ; the height of the mercury then being 27.72 inches. The mean annual height of the barometer at this town, as obtained from my observations made morning, noon, and night during twelve years, com- 